\title{
Selective consent and dissent: Professional response to reform in the post- crisis Greek NHS
}

\section{Sharon C. Bolton}

University of Stirling, UK

\section{Vasilis Charalampopoulos}

University of Stirling, UK

\section{Lila Skountridaki}

University of Stirling, UK

Corresponding author: Lila Skountridaki, Management Work and Organisation, Stirling Management School, University of Stirling, FK9 4LA, UK

Email: lila@skountridaki.com

\begin{abstract}
Utilising the sociology of the professions as an analytical framework, the article explores the response of the Greek medical profession to state-imposed managerialism during times of economic recession and socio-political turbulence. It is argued that the case of Southern welfare states, permeated by clientelism and corruption, underpins a distinct form of professional-state relations, currently missing from relevant theoretical discussions. Rich qualitative data collected from practising hospital doctors in Greece reveals a willingness to concede elements of clinical autonomy in exchange for the minimisation of the role of a corrupt state in the organisation of the Greek National Health Service.
\end{abstract}

\section{Keywords}

Clientelism, Doctors, Greek National Healthcare Service, Managerialism, Professional power 


\section{Introduction}

While formal healthcare became established in Europe typically in the aftermath of WWII, a national healthcare service, based on the philosophy of the British NHS, was only established in Greece in the 1980s. The ESY (Ethniko Systema Ygeias translated as National Health System) has since evolved in a fragmented manner due to the overwhelming presence of party-political competition, political favour and corruption (Spanou, 2008). ESY is often depicted as an inefficient, inward-looking bureaucracy (Sissouras, 2012; Tountas et al. 2005), where rigidity, regularity, legalism and strong bipartisanship (Spanou, 2008) cultivate a climate that inhibits the implementation of reform initiatives (Mouzelis, et al. 2005; Dikeos, 2011). Against this background, commentators suggest that political willingness for reform has been absent and/or lacks cohesion (Pelagidis, 2005; Economou, 2010; Sissouras, 2012; Philippidou, et al. 2004; Antonopoulou, 2014).

New initiatives, presented as managerial effectiveness but most prominently enacted as austerity measures, were introduced in 2009 under the surveillance of the Troika (the IMF, the European Commission and the Central Bank) (Kondylis, et al. 2008). Policies implemented include the reduction of the public sector workforce, curtailment of public expenditure, imposition of strict centralised controls, rationalisation in the allocation of resources and introduction of competition, among others. In particular, hospital closures and mergers of clinics within hospitals since 2011 (Kaitelidou and Kouli, 2012; Polyzos et al., 2013), along with the application of electronic platforms as a means of facilitating an evidence-based working culture have been a priority. Such changes significantly impact upon ESY staff. Medical doctors, who are the focus of this article, experience salary cuts, intensified workload, lack of medical supplies, hospital mergers and increased managerial control over their professional practice.

The aim of this article is to examine the response of medical professionals to managerialism under conditions of extreme austerity within a Southern European welfare state system ${ }^{1}$. Utilising the sociology of the professions as an analytical framework, it is argued that the much-discussed dynamics of professional dominance does not account for scenarios where the state, irrespective of the motives for intervention, is not perceived as impartial, but as relying on political patronage and corruption within public provision. Drawing on rich qualitative data collected from practising hospital doctors in Greece, the empirical case presented here suggests that, against the background of a state which lacks legitimacy in the eyes of doctors, reaction to managerialism is complex; a combination of 
selective consent and dissent, which ultimately reveals a willingness to concede clinical autonomy in exchange for the minimisation of the role of the state in the organisation of the ESY.

\section{Professional Power and Relations with the State: Doctors and the ESY}

The relationship between professionals and the state, and the impact of the introduction of managerialism into the public sector, has for over a quarter of a century been a feature within the sociology of the professions (Dawson et al., 1995; Spehar et al., 2012; Reed, 1996; Flynn, 1999; Kirkpatrick et al., 2007; Kurunmäki, 2004; Waring and Curie, 2007; Montgomery, 1990; Hoff, 1998; Forbes and Hallier, 2006). A wealth of studies explore the response of professionals to state imposed managerialism and the ramifications for professional power and autonomy. International literature promotes a better understanding of professionalism and managerialism alike and emphasises the significance of national and sectoral differences (Kirkpatrick et al., 2007; Kurunmäki, 2004; Waring and Curie, 2007; Numerato et al., 2012; Carlsen and Norheim, 2008; Lawton and Parker, 1999). The focus here is on professional power and the Greek medical profession's response to the introduction of managerialism into the ESY, within the distinctive context of a South-European welfare state; a context that is scarcely mentioned in discussions concerning professional power.

\section{Professionals and the state}

Sociology of the professions offers several accounts of the evolution of doctors' professional power; the relationship with the state is potentially the most crucial (Johnson, 1972; Larson, 1977; Burrage and Torstendahl, 1990). There are two distinct models offered, the AngloSaxon and the Continental (Burrage and Torstendahl, 1990). In the US and UK, with the establishment of a universal healthcare system, public health was entrusted to medical professionals as the latter were, at the time, the most convincing in their ability to take responsibility for public health (Larson, 1977; Johnson, 1972). As a result, and in return, doctors as an organised group gained access to a 'guaranteed clientele' (Johnson, 1972: 78). Mutual benefit has been the cornerstone of long-term collaboration and doctors, alongside other professions, have become an established part of the welfare state and the administration of citizen rights (Bertilsson, 1990). That is so in national contexts beyond the Anglo-Saxon case; continental professions developed alongside the growth of the state and monopolised government careers creating 'an elite bureaucratic hierarchy' (Collins, 1990: 16). Despite their differences, both the Continental and Anlgo-Saxon models highlight professions' 
dependence upon the state and the broader politico-economic context for the concession of power and privilege.

The Southern, Southern European, or Mediterranean (welfare) states merit special attention (Art and Gelissen, 2002). Fragmentation, dualism and ineffectiveness is identified in Spain, Greece, Italy and Portugal in the distribution of benefits; and particularisticclientelistic welfare provision (Art and Gelissen, 2002; Ferrera, 1996; Liebfried, 1992; Bonoli, 1997). Clientelism is a particular feature observed in a number of Southern European (Ferrera, 1996), Mediterranean (Gal et al., 2010) or Global Southern (welfare) states (Piattoni, 2001). It involves 'the misuse of public power for private personal or party gain' (Ongaro 2009: 227), and refers to the exchange of 'votes and other types of partisan support' for 'public decisions with divisible benefits' (Piattoni, 2001, pp.4-5), including jobs in public administration, social benefits, tax exemptions or inadequate tax collection, subsidies, public investment, or government contracts (Afosno et al., 2015). While clientelism is typically underlined by a dyadic informal relation between the client and the patron, often permeated by a sense of obligation and attachment (Piattoni, 2001, p.9), mass clientelism is developed between political parties and beneficiaries (Afonso et al., 2015) through the membership of the latter to a party or organisations such as trade unions.

In contrast, the Anglo-Saxon case and to a lesser extent the Continental or Nordic models, are characterised by relatively higher degrees of universalism in the distribution of welfare benefits and rights and lower degrees of political penetration and institutionalised corruption. The most relevant to this article is the prevalence of political clientelism in the Greek state and its consequences for the function of public provision and administration of social benefits. Recent work featuring Greece in the post-crisis austerity era has revived debates over clientelism in its exploration of the causes and effects of the crisis on the public sector.

Clientelistic practices have taken several forms in Greece since the 1980s, and are often linked to corruption (Pappas, 2013; Afonso et al., 2015). Mass clientelism flourished via political party structures and mechanisms (Lavdas, 2005; Mitsopoulos and Pelagidis, 2011; Pappas, 2013; Afonso et al., 2015), and throughout the 1990s and 2000s, led to an irrational expansion of the public sector along with inefficiencies and low productivity, unjustified increase of welfare spending, rampant tax evasion and misappropriation of social benefits or public land and normalised nepotism in recruitment practices (Pappas, 2013; Zartaloudis, 2014). Within the ESY, for example, more often than not hospital managers are appointed based on political party affiliation rather than qualifications (Liaropoulos et al., 
2012) and hospital procurement contracts and the outsourcing of services to the private sector are exchanged for political support (Mpourdaras, 2017). Moreover, doctors often oversubscribe medication to gain personal benefits from pharmaceutical companies and diagnostic laboratories (Mossialos et al. 2005, Minogiannis 2012), or receive informal payments from patients by promising better treatment (Dent 2003b, Mossialos et al. 2005). Most importantly, clientelistic relations have hindered politicians taking a strong stance against corruption.

\section{Professionals, the state and managerialism}

Professional power has multiple dimensions (see Tousijn, 2002) but is often conceptualised at two levels. At the macro-level, professions have the power to influence public policy and the organisation of service provision, often through collective mobilisation (Freidson, 2001). It is linked to both the strength of organised medicine and its relation with the state. Medical associations in the UK and the US, for example, have been influential at the macro level; they have legitimacy as 'guardians of public health', control licencing and, therefore, the aggregate supply of professionals and have collective voice in opposing new polices that undermine their power base (though admittedly not always successfully) (Bolton et al, 2011; Harrison and Ahmad, 2000; Kirkpatrick et al., 2009). In the Continental model, despite the growth of professions within the bureaucracies of the welfare state, empirical research shows similar collective mobilisation in response to challenges to the professional base of power (Spehar et al., 2012). At the micro-level, professionals enjoy autonomy in their daily work when there is limited bureaucratic or market interference and they are able to exercise control over the division of labour and resources (Freidson 2001). It has allowed the development of collegiality, the transmission of knowledge and support among members of the same profession and at the same time dominance and control over other occupational groups; with the control of nursing by doctors being the most obvious example. Freidson (1985) suggests that medical dominance is heavily reliant on micro-level autonomy, even in the absence of influence over policy making or control over the conditions and terms of work.

Irrespective of historical conditions and organisational structures within which professions are conceded privilege by the state, there are a wealth of studies on the efforts to maintain power in the face of increasing managerialism, i.e. a reliance on professional managers, rather than practicing professionals, to organise and control organisational activity and resources. A model of professional dominance - state intervention - collective/individual professional response is typically employed to highlight occupational change and the 
restructuring of service organisations in a variety of national contexts. In particular, medical professionals' response to managerial reforms ranges from dissent, resistance, direct conflict with the state and alienation from managerial ranks (Harrison and Ahmad, 2000; Bolton, 2005; Dawson et al., 1995; Spehar et al., 2012; Reed, 1996; Flynn, 1999), to engagement, assertion of ownership of managerial practices, 'co-optation' and 'hybridisation' of medical with management practices (Kirkpatrick et al., 2007; Kurunmäki, 2004; Waring and Curie, 2007; Montgomery, 1990) and/ or to a pragmatist embracing of managerialism from younger doctors who see a career path in healthcare management leading to re-stratification of the medical profession (Hoff, 1998; Forbes and Hallier, 2006; Dawson et al., 1995; Skountridaki, 2015). To an extent, dissent or consent is a continually unfolding dynamic and complex picture that depends on how doctors perceive the incentives behind and outcomes emanating from changes. For example, when doctors are convinced that changes will genuinely improve provision (Numerato et al., 2012) they may be supportive. In contrast, doctors are cautious about interventions that promote financial targets when they are not convinced these are coupled with improved clinical outcomes (Carlsen and Norheim, 2008), or when their clinical discretion and autonomy is curtailed (Lawton and Parker, 1999). In cases of consent, management tools may either not be perceived as a threat to clinical autonomy; or doctors strategically adopt them to protect their autonomy and own interests (Numerato, et al., 2012). The current article contributes to this rich body of literature through the examination of a Southern-European context.

\section{Reform and the Greek National Health Service}

The Greek public health sector employs 70,000 medical staff. 50,000 doctors and 20,000 nurses suggests an over-supply of doctors and a major deficit in nursing and midwifery (OECD 2015). Hospitals are characterised by bureaucratic procedures, informal payments and inefficiencies arising from poor management. For example, lengthy formal and yet highly subjective procedures of evaluating employees' performance are evident (OECD 2009); lacking transparency or incentive (Kufidu et al., 1997). Included in a long list of weaknesses in the ESY are a low level of primary healthcare (Tountas et al., 2002), lack of evidencebased information (Economou and Giorno, 2009) and few appraisal tools that support the measurement, control and efficiency of the system (Sissouras 2012). Historically, endeavours to modernise the public service in Greece have been unsuccessful (Kufidu et al., 1997; Zampetakis and Moustakis, 2007); constrained by political competition, bureaucratic structures and an absence of managerial planning (Sotiropoulos, 1996; Pelagidis, 2005; 
OECD, 2009). As a policy framework, managerialism arrived in Greece slowly throughout the 1990s (Zampetakis and Moustakis, 2007; Spanou, 2008) with limited results. New policies were developed to improve efficiency, and yet most were unsuccessful (Economou and Giorno, 2009); hindered by a shortage of financial resources and a lack of cohesion, support and the political will to implement systemic change (Philippidou et al., 2004; Pelagidis, 2005; Sissouras, 2012; Antonopoulou 2014).

Nevertheless, somewhat paradoxically, there is an argument that in Greece managerialism has the potential to transform the public sector utilising internationally benchmarked standards, (Sotirakou and Zeppou 2006, Economou and Giorno 2009, OECD 2011, Liaropoulos et al. 2012), which are enthusiastically endorsed by TROIKA; such as competition, evaluation, monitoring and control (Pelagidis, 2005). A key message being that crisis will bring renewal and that austerity is an opportunity for the national health system to become efficient and re-energised (Karamanoli, 2011).

\section{Medical Dominance in Greece: Fragmentation and Organisational Weakness}

Despite the establishment of a national health service in 1983 and the expansion of health care facilities across Greece, the state has not conceded power to organised medicine. The mass recruitment of doctors, in what proved to be a highly corrupt and inefficient bureaucratic organisation, and the (initial) restrictions on private provision (not least the nationalisation of most private hospitals), effectively downplayed doctors' collective power. A number of notable factors account for their inability to influence public policy. First, official medical associations in Greece are public institutions and act on behalf of the state. They operate under government surveillance, while their advisory role to the ministries is effectively downplayed (Colombotos and Fakiolas, 1993). Furthermore, the medical community does not control credentialing, or the number of medical school graduates. Training of medical professionals is under the surveillance of the Ministry of Education and licensing is provided by the Ministry of Health (Economou, 2010). As in France (Wilsford 1993), in Greece the establishment of new medical schools by the state (during the 1980s) led to an oversupply of doctors which was out of their control. Perhaps the greatest challenge of organised medicine remains the penetration of political parties into medical associations (Colombotos and Fakiolas, 1993). This is represented by association leaders who have been open supporters of the two largest parties (PASOK and New Democracy) succeeding one another in power since the mid-1970s (at least until the time of data collection). As a result, while associations support or struggle against healthcare plans (very often through strikes) 
(Nikolentzos, 2008; Mossialos et al., 2005) their stance depends on the association leader's party affiliation (Colombotos and Fakiolas, 1993). Fragmentation along party political lines is not a unique configuration; similar observations are made of the medical profession in Italy (Krause cited in Hafferty, 1988) and, for a period, in Canada (Coburn, 1993). Overall, internal fragmentation and organisational weakness accounts for the inability of doctors to effectively influence public policy due to their fragile relations with the state.

However, Freidson (1985) suggests that medical dominance is retained even under extreme external pressure if medical professionals maintain control over the content of their work. Micro-level autonomy is thus a core dimension of medical power. Within the ESY absence of control over doctors' work is evidenced by lack of role descriptors, work allocation models, or institutionalised performance measures (Polyzos and Yfantopoulos, 2000). While the 'production of producers' (Larson, 1977) is controlled by the state, medical specialisation remains in the hands of doctors within the public sector (Andri and Kyriakidou, 2014). Furthermore, access to care has been at the full discretion of doctors; efforts to introduce managerialism during the last two decades has not resulted in administrative control over patient admissions or treatments. In addition, while in several countries the formation of public healthcare resulted in the state directing the doctor-patient relationship (see Doolin on New Zealand, 2002 or Coburn on Canada, 1993), in Greece consultation with a doctor based on patient preference is a continuing practice. Relying on word-of-mouth, patients often book appointments with specialists in a fashion similar to the private sector. Lack of primary care to ensure gatekeeping further facilitates a direct relationship that is often fuelled by illicit out-of-pocket payments, depending solely on doctors and their demands. It is notable that in over three decades since the establishment of the ESY, the state does not control informal user-fees to doctors, and has not replaced the 'contract' between practitioner and patient. Indeed, some doctors redirect patients to private practices and diagnostic centres they are affiliated with (Andri and Kyriakidou, 2014). Arguably, either formally or informally, the uninterrupted patient-doctor relation constitutes a key aspect of medical autonomy in the ESY.

Overall, evidence suggests that medical power within the ESY is maintained at the micro-level and to a certain extent is sustained against the background of state negligence and political inability to implement reforms. At the macro-level, given political party penetration into medical associations and state interventions into the ESY to serve political interests, doctors have not convincingly managed to promote their interests or influence policy making. While Greek medical professionals bear resemblance to continental professions 'bred' in 
state bureaucracies, or much like the Anglo-Saxon case benefit from increased autonomy at the micro level, they depart from both models in that their relationship with the state is underlined by its corrupt nature, often characteristic of Global Southern national contexts. As such, research into changing state-profession relations would benefit from insights from Southern welfare models, and the particularities (or historic weaknesses) of states such as Greece, Italy, Portugal and Spain which are largely neglected in the sociology of the professions.

\section{Research Process}

The data analysed in this article are part of a research study examining the broader impact of the introduction of post-crisis managerialism into the organisation of the ESY. Fieldwork included 42 qualitative interviews with doctors, hospital managers and policy makers; conducted during the summer and autumn of 2013. The article draws on the narratives of 20 doctors working in the ESY, resulting in circa 40 hours of rich qualitative data. Participants mainly work in hospitals, except for two working in health centres; and are geographically dispersed with the majority working in Athens and others in the periphery. All participants have a specialisation (pathologists, a neurosurgeon, pulmonologists, anaesthesiologists, oncologists, or laboratory clinicians among others); have different length of service, varying from two to twenty-five years, with the majority being senior clinicians with over 5 years of experience in hospitals. None of the doctors hold a managerial position.

Convenience sampling was employed to identify potential interviewees. Snowballing also facilitated the process with some participants recommending their colleagues as interviewees (only two doctors work in the same organisation). The sample, though small, is diverse. The research plan included invitations to 50 doctors. However, many of those approached did not wish to speak about change to ESY in the political climate at that time. Those participants who did engage showed keen interest in the research topic, explained by the major impact policy changes have had on their working lives, which facilitated lengthy, in-depth discussions with the interviewer. The interviews were semi-structured in that they specifically explored participants' views on the effectiveness of new measures and tools (such as hospital mergers; e-prescription; DRGs' etc.), the effectiveness of the reforms as a whole, the past and present organisational challenges of the ESY and anticipation or aspirations about the future. At the same time, the conversations were relaxed and doctors appeared to grasp the opportunity to deliver rich descriptions of how newly implemented 
management practices impacted their day-to-day working lives, and to be open (and strongly opinionated) about past and present political reform. In the narrative tradition, and in keeping with the main objective of the analysis; that is to understand Doctors' responses to health care reform, the doctors' storytelling is accepted as an accurate interpretation of their lived experience (Chell, 1998; Rhodes and Brown, 2005; Silverman, 2015). In this spirit, the recorded interviews were transcribed verbatim and translated from Greek to English by the researcher involved directly in the interviews. The translated interviews were then reviewed by the co-authors and any queries checked against the original recording to ensure that nothing was lost in translation. It was not until the data analysis that the authors felt that the doctors' responses shed new light on debates concerning the relationship between the state, professionals and managerialism. The contribution of the sociology of the professions as a conceptual framework, became clear during the first round of data analysis and was further developed in subsequent immersion in the data. Repeated themes had a number assigned and were organised into several logical thematic parts. The analysis of doctors' narratives show that an interrelation of their perspectives and experiences with concepts from the sociology of the professions, lead to valuable empirical and theoretical contributions. In particular, clientelism and corruption, emerged as a key topic.

The analysis of the data highlights that the Southern case of professionalism merits special attention. In light of this, and bringing the sub-themes together, the data is organised into three main themes. The first explores doctors' emphasis on the long-established interventions of a clientelistic state and its link to the on-going problems of the ESY since its establishment. The second and third themes suggest how the first preconditions consent to specific managerial tools and dissent to others; in particular, doctors emphasise the collapse of clientelism as a priority in solving chronic problems and suggest that, on the one hand, managerialism can serve as a tool in promoting impartiality and the restraint of particularism, but on the other, it potentially accelerates the system's disintegration through its lack of strategic direction.

\section{State Negligence, Political Expedience, Clientelism}

A pervasive belief among doctors was that deeply entrenched structural problems afflicted the ESY. They almost unanimously considered political parties responsible for poor management practice, which they perceived as a hostage to state negligence and political clientelism. A chorus of critical voices depicted the ESY both in the past and now as a terrain 
where politicians served party interests by hiring and promoting their voters; while simultaneously remaining unaware and indifferent to the needs of the service (in terms of staffing, organisation and procurements), or voted for healthcare reforms without being able to put into effect or monitor their implementation. Doctors gave their own account of how clientelism has become a deeply entrenched institution undermining the ESY since its conception.

They have to repair the engine; how people are hired; how things are managed; everything... this situation is an outcome of 'partycracy' [...] Party members made a living from their party; made illicit money from their party...[...]. This is what the political parties are...the wound...and they will remain as such for as long as the state remains as powerful [in the ESY] as it is (Doctor 17).

I believe that PASOK created a big monopoly in health. You couldn't make a career inside a public hospital if you did not have connections to PASOK (Doctor 1).

Often debated among doctors was the presence of strong bipartisanship and its consequences; which they believed included: the partial implementation of policies, perpetuation of clientelistic relations, an absence of performance management, understaffed clinics, little perceived procedural fairness in the allocation of work among employees and no repercussions in cases of bribery or corruption (Antonopoulou, 2014; Economou and Giorno, 2009; Mouzelis et al., 2005; Papoulias and Tsoukas, 1994; Philippidou et al., 2004; Sissouras, 2012; Spanou, 2008). Overall, doctors experienced the administration and high-level management of the ESY as negligent, indifferent to organisational needs and ultimately as a means to political parties' ends.

It is not difficult to understand [the needs of the ESY]; they [policy makers] simply don't want to. They do not bother or they are superficially concerned, they simply see the problems but have no sense of how to solve them and how to proceed with implementing changes (Doctor 13).

As far as I remember many new appointments were taking place each time the governments were changing. All the hospital managers were changing as well. And then it depended on the manager on how good [s]he was and on his [her] willingness to deal with our problems [...] those hired as managers had no experience in the 
field, they could be party members and completely irrelevant to the healthcare sector (Doctor 3).

These accounts are illustrative of the lived experience of working for the ESY. It is notable that a number of doctors also referred to their disappointment in the actions of fellow doctors, in addition to administrators and at the ministerial level. Interviews emphasised poor planning (with a prime example being the lack of primary care), vested interests, inefficient use of resources, thoughtlessness and personal irresponsibility. Overall, doctors were concerned about the future of the ESY and, against the background of the national economic crisis, considered changes to be legitimate. They suggested that the 'debt crisis is a chance for health care in Greece to progress'; an opportunity for the ESY to renew and operate more effectively (Karamanoli, 2011). Doctors' widespread disappointment with the state's role in the institutionalisation of inefficiencies and corruption within the ESY underpins such perceptions.

\section{When Managerialism Succeeds}

It is suggested that, at least partially, managerialism has been introduced in the UK to successfully control professional power (Muzio and Ackroyd, 2005). The findings of this research indicate, somewhat ironically, that managerialism was perceived by Greek doctors as a tool to restrain a negligent state. As such, in the eyes of the doctors, managerialism can serve, in principle, as a vehicle to hamper the structural (politically-laden) problems; and gains legitimacy when it effectively promotes transparency. Arguably, Greek doctors maintained an open stance towards managerialist policies.

Absolutely [managerial tools should be introduced to the public sector], everything needs a theoretical compass to function properly, checks and controls, it shouldn't be just left to the personal ethos of staff (Doctor 6).

We need transparency, open discussions and basically a well-organised plan [...] If management is independent, something that is not linked to the creation of micropolitics then it can offer solutions (Doctor 19). 
Some newly introduced managerial tools and practices were popular among doctors. For example, despite technical problems, they supported electronic drug prescription. The vast majority believed that it both encouraged transparency in the consumption of medication and helped reduce pharmaceutical expenditure. And while several interviewees doubted that incidents of over-prescription would be effectively dealt with by the ministry (e.g. through sanctions and fines), nevertheless, it was widely acknowledged that electronic record keeping discouraged drug over-prescription and overconsumption; promoted accountability; and supported cost-rationalisation.

E-prescription is a positive step. It takes too much time and time is quite valuable because of the overloaded schedule of doctors and administrative staff. But, definitely, record keeping is important (Doctor 19).

E-prescription, I believe, has already solved problems; for example, the issue of over-prescription, which is most possibly the reason why it was implemented in the first place. In these terms it is effective [...] and will mean even greater progress both for patients and doctors (Doctor 8).

The adoption of clinical protocols (DRGs) was also largely supported as an effective tool against irrational spending. Interestingly, support was not grounded on medical reasoning; rather it was mainly budgetary targets that medics believed protocols contributed to.

We have implemented the DRGs and certainly hospitalisation costs are not uncontrolled as in the past [...] of course medicine is not math, 1+1 is not always 2, it is $2.1,2.2,1.8$, but on the other hand one cannot be charging the insurance fund double hospitalisation time or...supplies for example. We need a stick to measure (Doctor 6).

We should simply have a better check or distinction among medical cases, based on strict criteria [...]. Then, during treatment the particular health problem should be dealt with based on contemporary guidelines, the latest protocols...how many days and what [treatment]. In this way a lot of money would be saved [...] implementing strict rules, however, should not be confused with trying to make an organisation private... (Doctor 3). 
The Greek case suggests that doctors carefully considered the incentives behind and outcomes emanating from each measure or tool. Doctors resorted to their clinical expertise and, thus, fiercely guarded their micro-level autonomy in making a case for an effective public health service rather than supporting managerialism per se. As a result, they may have acknowledged the need for change and supported some measures but simultaneously vehemently dissented to others.

\section{When Managerialism Fails}

Doctors expressed reservations about a number of measures on the basis that they were not evidence based and hence lacked transparency and, by association, they exacerbated structural problems in the ESY. Initiatives that left space for too much discretion in their enactment were not considered useful or effective as change was perceived to be steered by the same political forces that managed the ESY in the past. For example, doctors almost unanimously argued that mergers of clinics and hospitals were not evidence-based and did not follow rational criteria. Rather than considering population needs, e.g. needs of the geographically remote areas, the mergers were arbitrary, at best, and determined by political favouritism, at worst.

We underwent a forced merger because one clinic did not have personnel [...] They will close four to five more clinics. Everything is clumsily made, without being supported by data, evidence, or being based on the real needs of this country. There are no economic criteria. In our hospital they will only keep the clinics with directors. They don't care if the other clinics work properly or if they have small costs. And this is happening due to political reasons, micro-politics, this is 'my' manager, the other is not 'mine', the usual, same people in power, what would change? (Doctor 17).

I am not against mergers, I think it would help [the situation], we were saying that the National hospital has 3 gates and 36 guards [...] but it has to take place in the right way, well, it won't; because we will have the merger and the party members and trade union officials will still be included (Doctor 15).

The majority of doctors argued that the new wave of reforms imposed by the TROIKA are aimed at reducing costs without addressing structural problems and without controlling for 
negative consequences for patients and staff. Doctors felt strongly about the impact of austerity on the quality of care provided to patients, as well as their own well-being.

Our salary has been reduced by $60 \%$. Some have lost their appetite to work. Most keep working under such conditions because medicine is a passion. But I realise that they are unhappy. [...] They work more than before because patient volume has increased; however, they feel disappointed. And there is no way out (Doctor 1).

Doctors were concerned that, albeit essential, cost-containment had gone too far and they expressed ongoing frustration that little appeared to be done to fight the corruption that created cost inefficiencies.

I believe that rationalisation of costs was necessary in the ESY, but I believe it has crossed the limits and the system cannot manage it without compromising the quality of care. And I am not convinced that the 'party' in procurements is over. The situation is better, but I think when they can do the job [misappropriation], they do it (Doctor 12).

A recurrent theme in the data was suspicion of the neo-liberal motivations that lay behind the new measures and feared that the public character of healthcare provision was under pressure. In particular, they saw the ESY 'shrinking' in its capacity to serve the public, rather than cost reductions coming from meaningful, deep-rooted change.

There are serious issues but they [policy makers] do nothing about it. These problems cannot be solved by bringing in private companies. There is a private company in this hospital, cleaning service, and they pay their employees 600 Euros on paper. These employees cost much more to the state than a public servant. Because the private company pays a bribe and now cleaning services cost 2,000,000 a year to the hospital. And do you know how much the employees earn? Not even 600 , when they go to get their salary, they get 100 less as there is a fee to the company. And if they say something they get fired (Doctor 4).

A range of empirical research indicates that doctors object to managerial practices constraining their autonomy, when they are not convinced that they enhance patient care but instead believe the motives behind their introduction are purely financial or a means to 
manage organisational risk (e.g. avoid litigation) (Carlsen and Norheim, 2008; Lawton and Parker, 1999). Interviewees acknowledged that there is more to be done but they did not welcome the cruel face of austerity. What they hoped for was rationalisation while protecting the public character of healthcare; new tools and managerialism but not outsourcing and/ or cost containment which undermined the ESY to the benefit of private interests.

\section{Discussion}

Doctors in the Greek public sector have long enjoyed micro-level autonomy (including patient admission, diagnosis, treatment and medical prescription among others) and escaped external pressures, largely owing to incomprehensive and ineffective ESY reforms. In contrast, at the macro level, organised medicine in Greece is fragmented along the lines of party politics, has little control over the supply of professionals in country and holds a downplayed role in healthcare policy by the state. Professionals' relation with the state is permeated by political party competition as much as the ESY has been affected by clientelism and political negligence. The latter social arrangements draw attention to the case of Southern welfare states as underpinning distinct forms of professional-state relations.

Against this background, this article focuses on the most recent healthcare reform which took place under the auspices of the TROIKA during the debt crisis, which involves the introduction of managerial tools into the ESY. There is a particular interest in the perceptions and lived experiences of doctors and how they respond to managerialism under conditions of extreme austerity within a Southern welfare state. Given that managerialism has often been perceived as a threat to professional autonomy in a variety of contexts, a key finding of this analysis is that Greek doctors paradoxically present managerialism as an opportunity to restrain a negligent and corrupt state. An important conclusion that might be drawn is that the nature of the state and its interventions deserves re-examination. The article suggests that the well-established model of 'professional dominance - state intervention collective/individual professional response' is significantly different to a model where the state is considered corrupt and its interventions illegitimate, implying instead a model of 'professional dominance - corrupt state intervention - collective/individual professional response'. While some previous research studies refer to suspicion and doubt over the incentives of (managerial) interventions (Lawton and Parker, 1999; Kirkpatrick et al., 2009; Carlsen and Norheim, 2008), Greek doctors explore the ramifications of a corrupt state on the state-professional relation. The Greek case suggests that while the literature on the sociology 
of the professions has examined the Anglo-Saxon case and, increasingly since the 1990s, the continental and Nordic cases as distinctive in terms of state-professional relations, a model of professional-state relations in a 'southern' context is missing. In such a context data presented here suggests that tensions are not observed between clinical and managerial logics per se. Rather, it is a clinical/managerial orientation that is in tension with politicised/corrupt decision making within the ESY.

Importantly, as the theoretical focus is moved to professionals' response to the nature of the state, doctors' ambivalent response to managerialism can be better explained. On the one hand, one group of measures are perceived in positive terms as conducive to transparency and efficiency and therefore effectively addressing deeply structural problems. For example, doctors consent to increased control over treatment planning (via international clinical protocols), tight monitoring over prescription practices (via an electronic register) and hospital organisation by non-clinical managers. The analysis indicates that consent is supported by a belief that the aforementioned measures move in the right direction to offer an enhanced national healthcare service. In contrast, measures that do not challenge corruption and clientelism are perceived as ineffective: doctors refer to mergers that often serve party interests rather than improve patient care and accessibility to services; or they lament excessive cost containment that undermines the quality of care and places staff's health at risk, and they express dissatisfaction with the outsourcing of services to the private sector, that do not exclude bribery but promotes precarious forms of employment. Doctors bemoan that political games continue within the ESY and emphasise that they and public health have been at the mercy of constant change without a clear and long-term strategic focus. Due to reservations about the reach and depth of recent changes, they continue to hope for liberation from a corrupt state.

What does that imply, however, for professional power? Greek doctors who took part in this study speak of support for bureaucracy and managerialism, but in an expedient manner as a means to weed out corruption and political clientelism from the ESY. This might compromise professional self-regulation and clinical autonomy, but at the same time is likely to bolster the standing of the profession and forms a strong foundation for enhanced claims to increased macro-level power. It is too early to track developments in the Greek medical profession and ESY due to recent changes and findings are based on a small, but diverse, sample of doctors. It may also be the case that the doctors who refused to be interviewed are a self-selected sample of non-respondents who hold opposing views and/ or are involved in corrupt practices and are, therefore, reluctant to speak. However, the rich qualitative data 
presented reveals remarkable consistency that presents opportunities to effect change as some doctors embrace and encourage further development of aspects of new management practices, gain confidence to break free from clientelism, reject the Draconian stance of Troika and ultimately forge a stronger professional identity as 'guardians of the nation's health'. The case of the Greek doctors potentially shows how broader structural constraints (here deep-rooted state corruption and clientelism) frame the quality of service and efficiency of the ESY and the response of professionals to managerialism.

\footnotetext{
${ }^{1}$ By managerialism we refer to bureaucratic control of public services (Freidson, 2001) and in particular 'the process of subjecting the control of public services to the principles, powers, and practices of managerial coordination' (Clarke et al., 2000, p.5). According to Freidson (2001) managerialism claims authority over the choices of citizens/ 'service consumers' and the work of experts/specialists such as professionals.
}

\section{References}

Afonso A, Zartaloudis S, and Papadopoulos Y (2015) How party linkages shape austerity politics: clientelism and fiscal adjustment in Greece and Portugal during the eurozone crisis, Journal of European Public Policy, 22(3): 315-334.

Andri M and Kyriakidou O (2014) Professional autonomy under pressure, Journal of Health Organization and Management, 28(5): 635-652.

Antonopoulou L (2014) Health Economics: Theoretical Approaches and Policies for the Greek NHS (in Greek). Athens: Gutenberg.

Arts W and Gelissen J (2002) Three worlds of welfare capitalism or more?, Journal of European Social Policy, 12(2): 137-58.

Bertilsson M (1990) The welfare state, the professions and citizens. In Torstendhal, R. and Burrage M (eds.). The formation of professions. London: Sage, 114-133.

Bolton, S. (2005) 'Making Up Managers: Nurses or Managers in the NHS?', Work, Employment and Society, 19, 2: 5-23

Bolton, S.; Muzio, D. and Boyd, C. (2011) Modernising Medical Careers, Sociology, 45, 4: 682-69 Bonoli G (1997) Classifying Welfare States: a Two-dimension Approach, Journal of Social Policy, 26(3): 351-72.

Burrage M, Torstendhal R (1990) Professions in Theory and History. London: Sage.

Colombotos J and Fakiolas NP (1993) The Power of Organized Medicine in Greece. In: Hafferty F, McKinlay J (eds) The Changing Medical Profession: an International Perspective. New York: Oxford University Press, 138-149. 
Carlsen B and Norheim OF (2008) 'What lies beneath it all?': an interview study of GPs' attitudes to the use of guidelines, BMC Health Services Research, 8, 218.

Clarke J, Gewirtz S, and McLaughlin E (2000) New Managerialism, New Welfare? London: Sage.

Coburn D (1993) Professional Powers in Decline: Medicine in a Changing Canada. In: Hafferty F,

McKinlay J (eds) The Changing Medical Profession: an International Perspective. New

York: Oxford University Press, 92-103.

Collins R (1990) Changing conceptions in the sociology of the professions. In Torstendahl R. and

Burrage M. (eds), The formation of professions. London: Sage, 11-23.

Dawson S, Mole V, Winstanley D, and Sherval J (1995) Management, Competition and Professional

Practice: Medicine and the Marketplace. British Journal of Management, 6: 169-181.

Dikeos C (2011) Two-Party Systems and consensus over health care policy in Greece and the United Kingdom. Journal of US-China Public Administration, 8 (7): 721-734.

Doolin B (2002) Enterprise Discourse, Professional Identity and the Organizational Control of

Hospital Clinicians. Organization Studies, 23: 369-390.

Economou C (2010) Greece: Health system review. Health Systems in Transition. 12(7): 1-180.

Economou C, Giorno C (2009) Improving the Performance of the Public Health Care System in

Greece. OECD Economics Department Working Papers No. 722. OECD Publishing.

Ferrera M (1996) 'The “Southern” Model of Welfare in Social Europe', Journal of European Social Policy, 6(1): 17-37.

Flynn R (1999) 'Managerialism, professionalism and quasi-markets'. In Exworthy, M. and Halford S (eds). Professionals and the New Managerialism in the Public Sector. Buckingham; Open University Press, 18-36.

Forbes T and Hallier J (2006) Social identity and self-enactment strategies: adapting to change in professional-manager relationships in the NHS. Journal of Nursing Management, 14: 34-42.

Freidson E (1985) The Reorganization of the Medical Profession. Medical Care Research and Review, 42: 11- 35 .

Freidson E (2001) Professionalism: The Third Logic. Cambridge: Polity.

Hafferty FW (1988) Theories at the Crossroads: A Discussion of Evolving Views on Medicine as a Profession. The Milbank Quarterly, 66(2): 202-225.

Harrison S and Ahmad WIU (2000) Medical autonomy and the UK state 1975 to 2025, Sociology, 34(1): 129-46.

Hoff TJ (1998) Physician Executives in Managed Care. Journal of Healthcare Management, 43(6):

91-111.

Johnson TJ (1972) Professions and Power. London: Macmillan. 
Kalafati M (2012) How Greek healthcare services are affected by the Euro crisis. Emergency Nurse, 20 (3): 26-27.

Kaitelidou D and Kouli E (2012) Greece: The health system in a time of crisis. Eurohealth Observer, 18 (1): $12-14$.

Karamanoli E (2011) Debt crisis strains Greece's ailing health system. The Lancet, 378 (9788): 303 304.

Kirkpatrick I Kragh JP Dent M, and Neogy I (2009) Medicine and management in a comparative perspective: the case of Denmark and England. Sociology of Health \& Illness, 31(5): 642658

Kondylis H, Antonopoulou L and Benos A (2008) Public and Private Partnerships in hospitals. (In Greek). Archives of Hellenic Medicine, 25 (4): 496-508.

Kufidu S, Petridou E and Mihail D (1997) Understanding managerial work in the Greek civil service. International Journal of Public Sector Management, 10 (4): 244-253.

Kurunmäki L (2004) A hybrid profession - the acquisition of management accounting expertise by medical professionals. Accounting, Organizations and Society, 29: 327-347.

Larkin G (1993) Continuity in Change: Medical Dominance in the United Kingdom. In: Hafferty F, McKinlay J (eds) The Changing Medical Profession: an International Perspective. New York: Oxford University Press, 81-91.

Larson MS (1977) The Rise of Professionalism: A Sociological Analysis. Berkeley, CA: University of California Press.

Lavdas KA (2005) Interest Groups in Disjointed Corporatism: Social Dialogue in Greece and European ‘Competitive Corporatism', West European Politics, 28(2): 297-316.

Leibfried S (1992) Towards a European welfare state?, in Z. Fergeand J. E. Kolberg (eds) Social Policy in a Changing Europe. Frankfurt am Main: Campus Verlag.

Liaropoulos L, Siskou O, Kontodimopoulos N, Kaitelidou D, Lazarou P, Spinthouri M, \& Tsavalias K (2012) Restructuring the hospital sector in Greece. Social Cohesion and Development, 7(1): 53-68.

Lawton R and Parker D (1999) Procedures and the professional: The case of the British NHS, Social Science and Medicine, 48(3): 353-61.

Light DW (1995) Countervailing powers: a framework for professions in transition. In Johnson T, Larkin S, and Saks M (eds.). Health Professions and the State in Europe. London: Routledge, $25-41$.

Mitsopoulos M and Pelagidis T (2011) Understanding the Crisis in Greece. Basingstoke: Palgrave Macmillan. 
Montgomery K (1990) A Prospective Look at the Specialty of Medical Management, Work and Occupations, 17: 178-198.

Mossialos E, Allin S, and Davaki K (2005) Analysing the Greek health system. Health Econ, 14: S151-S168.

Mouzelis N, Kazakos P, Kazamias A, Tsoukas X, and Pelagidis T (2005) The entanglement of reforms in Greece (in Greek). Papazisis Publications.

Muzio D and Ackroyd S (2005) On the Consequences of Defensive Professionalism. Journal of Law and Society, 32(4): 615-42.

Numerato D, Salvatore D, and Fattore G (2012) The impact of management on medical professionalism: a review, Sociology of Health \& Illness, 34(4): 626-644.

OECD (2009) OECD Public Management Reviews: Strengthening Public Administration Reform in Greece, Working Paper H5, unpublished. OECD Publishing.

OECD (2011) OECD Economic Surveys: Greece 2011, OECD Publishing.

OECD (2015) Health at a Glance 2015, OECD INDICATORS. Available: http://www.oecd.org/health/health-systems/health-at-a-glance-19991312.htm [Accessed 05 May 2017]

Mpourdaras GS (2017) Eksetastiki gia tin Ygeia apo SYRIZA-ANEL, Kathimerini. Available: http://www.kathimerini.gr/903137/article/epikairothta/politikh/e3etastikh-gia-thn-ygeia-aposyriza-anel [Accessed 05 May 2017]

Ongaro E (2009) Public Management Reform and Modernization. Cheltenham: Edward Elgar.

Pappas TS (2009) Patrons against Partisans: The Politics of Patronage in Mass Ideological Parties, Party Politics, 15(3): 315-334.

Pappas TS (2013) Why Greece failed, Journal of Democracy, 24(2): 31-45.

Pelagidis T (2005) The Blockage of Reforms in Greece (in Greek). Athens: Papazissis.

Piattoni S (2001) Clientelism, Interests, and Democratic Representation: The European Experience in Historical and Comparative Perspective, Cambridge: Cambridge University Press.

Polyzos N and Yfantopoulos J (2000) Health manpower development and National Health System staffing. Archives of Hellenic Medicine, 17(6): 627-639.

Polyzos N, Karanikas H, Thireos E, Kastanioti C, and Kontodimopoulos N (2013) Reforming reimbursement of public hospitals in Greece during the economic crisis: Implementation of a DRG system. Health Policy, 109 (1): 14-22.

Reed MI (1996) Expert power and control in late modernity: An empirical review and theoretical synthesis. Organization Studies, 17(4): 573-597. 
Rhodes, C. and Brown, A. (2005) Narratives, organisations and research, International Journal of Management Reviews, 7 (3), 164-188.

Sissouras A (2012) The suspended step of the Greek NHS, (in Greek). Kastaniotis Editions.

Skountridaki L (2015) The Internationalisation of Healthcare and Business Aspirations of Medical Professionals, Sociology, 49 (3), pp. 471-487.

Sotirakou T, Zeppou M (2006) Utilizing performance measurement to modernize the Greek public sector. Management Decision, 44 (9): 1277-1304.

Sotiropoulos D (1996) Populism and Bureaucracy: The Case of Greece under PASOK, 1981-1989. London: The Notre Dame University Press.

Spanou C (2008) State reform in Greece. Responding to old and new challenges. International Journal of Public Sector Management, 21(2): 150-173.

Spehar I, Frich JC and Kjejshus LE (2012) Clinicians' experiences of becoming a clinical manager a qualitative study. BMC Health Services Research, 12: 421.

Torstendahl R (1990) In Torstendahl R and Burrage M (eds), The formation of professions. Sage, London. 1-10.

Tousijn W (2002) Medical dominance in Italy: a partial decline, Social Science \& Medicine, 55 (5): 733-741.

Tountas Y, Karnaki P, Pavi E and Souliotis K (2005) The unexpected growth of the private health sector in Greece. Health Policy, 74 (2): 167-180.

Waring J and Currie G (2009) Managing expert knowledge: Organizational challenges and managerial futures for the UK medical profession, Organization Studies, 30(7): 755-778.

Wilsford D (1993) The State and the Medical Profession in France. In Hafferty F, McKinlay J (eds.). The Changing Medical Profession: an International Perspective. New York: Oxford University Press, 124-137.

Zampetakis Land Moustakis V (2007) Entrepreneurial behaviour in the Greek Public Sector. International Journal of Entrepreneurial Behaviour \& Reseacrch, 13(1): 19-38.

Zartaloudis S (2014) The Impact of the Fiscal Crisis on Greek and Portuguese Welfare States:

Retrenchment before the Catch-up?, Social Policy \& Administration, 48(4): 430-449.

Sharon C. Bolton is Professor of Organisational Analysis and Dean of University of Stirling Management School. Her research interests broadly cover the sociology of work with a particular focus on the emotional labour process, skills and employment, precarious work, meaningful work, public sector management, the nursing and teaching labour process, gender, management and the professions, and dignity in and at work. 
The origins of Sharon's research interests lie in some perennial questions concerning what is it to be human, and how we understand the relationship between people, work and society.

Vasilis Charalampopoulos is working in the Greek public sector. Vasilis finished his $\mathrm{PhD}$ at Stirling Management School where he examined the implementation of New Public Management as both practice and ideology into the Greek NHS at the time of financial austerity. As part of his Phd scholarship Vasilis tutored at the undergraduate level within the Management School. His research interests include the public administration, health reforms, and New Public Management. Prior to his PhD, he studied for a MBA in International Business (France), a MA in Industrial and Organizational Psychology (USA) and a BSc (Hons) in Business Administration (UK).

Lila Skountridaki is a Lecturer in Management and Sustainable Practice at the University of Stirling Management School. Her research interests include the sociology of the professions, medical sociology, and the internationalisation of health care. Her research explores the concept and practice of professionalism alongside occupational work ethics, through the study of medical doctors in the private/public sectors and most recently lobbyists. Her research in the field of transnational healthcare provision examines the lived experiences and relations among medical doctors, patients, and medical tourism brokers through conceptual frameworks including the ethics of care, politics of health, and the patient-professional interaction. 